\title{
Paediatric admissions to a hospital in the United Arab Emirates
}

K.P. Dawson' and D. Onyia'

$$
\text { كا. بالات أمراض الأطفال المقبولة في مستشفى بالإمارات العربية المتحدة }
$$

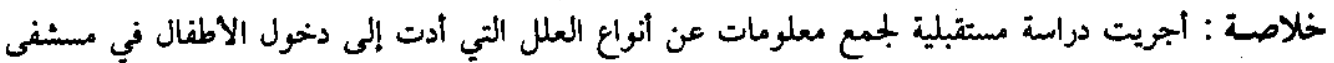

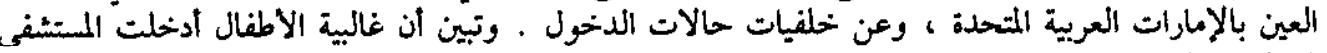

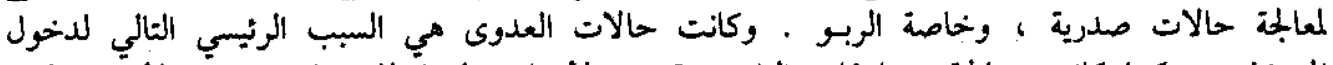

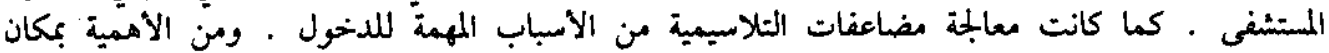

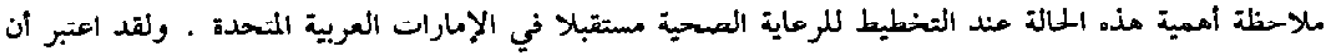

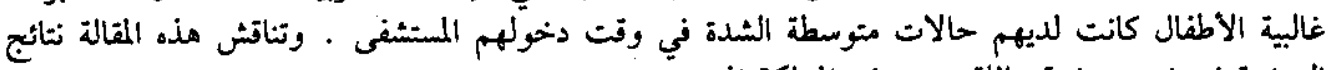

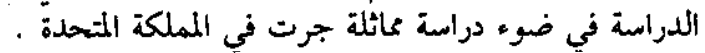

ABSTRACT A prospective study was designed to assess the types of illness which resulted in hospital admission in Al-Ain, United Arab Emirates, and the background to the admission. The majorty of children were admitted tor the management of a resplratory condltion, particularly asthma. Infections were the next major cause of hospital care. Management of the complications of thalassaemia was also an important reason for admission. The recognition of the importance of this disorder io neosesary for future hoalth care planning in tho Unitod Arab Emiratec. The majority of children were regarded as having a disorder of medium severity at the time of their admission. The results are discussed in light of a similar United Kingdom study.

\section{Admissions de ces pédiatriques dans un hopital des Emirats arabes unis}

RESUME Une étude prospective a été conçue pour recueillir des données sur les types de maladie qui entrainnaient une hospitalisation a Al Ain (Emirats arabes unis) et les raisons de I'hospitalisation. La majorité des enfants avaient été hospitalisés pour traiter une affection respiratoire, en particulier l'asthme. Les infections représentaient la deuxième cause principale de soins hospitaliers. La prise en charge de complications de la thalassémie constituaient également un motil important d'hospitalisation. La reconnaissance de l'importance de celte affection est nécessaire pour pouvoir planifier les soins médico-sanitaires dans le futur aux Emirats arabes unis. La majorité des enfants étaient considérés comme présentant un trouble de gravité moyonne au moment de lour admission. Los rósultats sont examinés à la lumière d'une étude analogue réalisée au Royaume-Uni.

'Dopartmont of Paediatrics, Faculty of Modicine and Health Sciencos, Unitod Arab Emiratos Univorelty and Tawam Hospital, Al-Aln, United Arab Emirates. 


\section{Introduction}

Differences in disease incidence are a major factor in the determination of hospital admission rates. They are, however, not the only factor which explains the marked geographic variation in paediatric hospital admissions $[1,2]$. There is considerable debate as to whether many hospital admissions for children are inappropriate or whether rapid referral for specialist assessment is important in the carly diagnosis of serious disease [3].

When attempting to assess the needs for children in terms of hospital beds in rapidly developing countries, the above-mentioned dual factors of disease patterns and hospital utilization need to be borne in mind. In light of the absence of local data, and to facilitate future planning for a proposed new children's hospltal in Al-Ain, United Arab Emirates, the authors have examined prospectively information acquired following the admission of children to a paediatric unit.

\section{Materials and methods}

Tawam IIospital. serves the indigenous population of Al-Ain, United Arab Emirates. Al-Ain is in the Abu Dhabi Emirate and has a desert location and a population of 300000 . It is also the site of the national University and Medical School of the United Arab Emirates.

Tawam Hospital is a university teaching hospital in which all major specialities are represented. There is a general paediatric ward and a tertiary neonatal unit. A separate paediatric oncology unit serves as a national unit and, for this reason, was excluded from this study, as was the neonatal unit. Surgical admissions go to a paediatric surgical ward.
A prospective study was designed to gather information about children admitted as first admissions to the medical pacdiatric ward of Tawam Hospital. Re-admissions were excluded from the study. The following data were collected: age, sex, source of teferral (e.g. Emergency Room), duration of stay (nights), background reason for admission (emergency, etc.), discharge diagnosis, method of discharge and follow-up, and a consultant's grading of the severity of the illness. For the grading, a subjective assessment of the condition of the patient at admission was made by the consultant responsible for the child's care in the hospital and was defined as: (1) danger of dying; (2) severely ill; (3) medium illness; (4) mildly ill; (3) not ill.

\section{Results}

The study period was from 2 September 1995 to 5 December 1995 inclusive, during which 337 admissions occurred; 176 males and 161 females. The mean age was 46.5 months $(s=40.84 ; 95 \%$ CI $42.16-$ 50.91 months) and their median age was 36 months. The minimum age was two days and the maximum was 16 years. The median duration of stay was three nights and the mean number of nights was 3.91 (95\% CI 3.362-4.451 nights).

The background to the admission and severity grading are listed in Tables 1 and 2. A medium degree of severity of the illness was the commonest assessment and acute illness was the usual reason for admission.

Patients were discharged in a regular manner, with follow-up arrangements to a paediatric clinic in 274 cases $(81.3 \%)$; discharge with no follow-up in 46 cases (13.6\%); discharge for general practitioner follow-up in 4 cases; transfer to another 
Table 1 Assessment of Illness severity

\begin{tabular}{lcc}
\hline Grado & $\begin{array}{c}\text { Number } \\
(\boldsymbol{n}=334)\end{array}$ & Porcontege \\
\hline Not ill & 67 & 20.1 \\
Mildly ill & 95 & 28.4 \\
Medium illness & 135 & 40.4 \\
Sovorely ill & 37 & 11.1 \\
Danger of dying & 0 & \\
\hline
\end{tabular}

¿Data were absent for three children

\begin{tabular}{lc}
\hline Table 2 Reason for admission \\
\hline Reason & $\begin{array}{c}\text { Number } \\
(\boldsymbol{n}=\mathbf{3 3 7})\end{array}$ \\
\hline Acute emergency & 30 \\
Diagnostic problem & 31 \\
Treatment only & 55 \\
Diagnostic procedure & 4 \\
Parental request & 1 \\
Administration request & 0 \\
Acute illness & 216 \\
\hline
\end{tabular}

United Arab Emirates hospital in 5 cases; and 3 children were discharged against medical advice. No data were available for 5 cases. Children admitted for a diagnostic procedure and specific treatment had standing follow-up arrangements. The diagnostic groups on discharge are listed in Table 3. The management of blood disorders and asthma were the two leading diagnostic areas identified.

\section{Discussion}

MacFaul et al. [3] published a study from the United Kingdom in which they reviewed 267 consecutive admissions to a district paediatric unit. Our study was carried out during the same season as the United Kingdom study. Their hospital was of a similar size and drew from a similar population base as ours. The major difference to be found in the patterns of admission was their high rate of asthma and croup which accounted for over $21 \%$ of their sample, against $16 \%$ of our sample, but the management of children with thalassaemia and sickle cell disease amounted to $17 \%$ of our total. The United Kingdom sample contained a surprising number of children with head injury who were admitted to a medical ward and a high number of ingestions. Febrile convulsions were a frequent reason for admission in the United Kingdom study, but were less so in our study. Fever and upper respiratory illness were equally represented in both samples.

The authors have atrempted to replicate MacFaul's findings in our group with regard to severity of the illness grading at admission; here there is a major difference between the two studies. Many more patients are regarded as having mild illness in the United Kingdom ( $54 \%$ versus $28.4 \%$ ) with medium graded illness more common in the Emirates than the United Kingdom (40.4\% versus $30 \%$ ).

Several factors emerged from this small study. The first, general patterns of paediatric disease requiring hospital admission are similar between this hospital in a rapidly developing country and in an industrialized United Kingdom centre. However, there are striking differences in the needs of patients with thalassaemia and sickle cell disease not seen in the United Kingdom. Thus, hospital planning needs to provide services for these important, inherited problems. In contrast to the United Kingdom sample, the authors had no admissions of children with head injury. This may reflect the close supervision of children by adults, especially

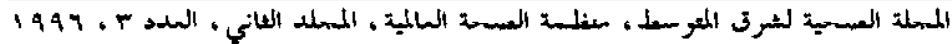


Table 3 Dlagnostic groups at dlacharge

\begin{tabular}{|c|c|c|c|c|c|}
\hline & Diagnostic group & Number & & Diegnostic group & Number \\
\hline \multirow[t]{4}{*}{ Blood disorders } & Thalassaemia & 49 & \multirow[t]{2}{*}{ Heart diseases } & \multirow{2}{*}{$\begin{array}{l}\text { Ventricular septal defec } \\
\text { Pulmonary stenosis }\end{array}$} & ect 1 \\
\hline & Sickle cell disease & 7 & & & 1 \\
\hline & Anaemia & 8 & Rickets & & 1 \\
\hline & Malignant disease & 1 & \multirow[t]{4}{*}{ Endocrine } & Precocious puberty & 1 \\
\hline \multirow[t]{10}{*}{ Respiratory } & Asthma & 44 & & Congenital adrenal & \\
\hline & Croup & 11 & & typerplasia & 1 \\
\hline & Upper respiratory & & & Investigation & 2 \\
\hline & $\begin{array}{l}\text { tract infection } \\
\text { Bronchiolitis }\end{array}$ & $\begin{array}{r}28 \\
9\end{array}$ & Convulsions & $\begin{array}{l}\text { Febrile } \\
\text { Epilepsy }\end{array}$ & $\begin{array}{l}5 \\
3\end{array}$ \\
\hline & Pneumonia & 31 & \multirow[t]{6}{*}{ Infections } & Cellulitis & 2 \\
\hline & dysplasia & 3 & & Malaria & 3 \\
\hline & Chronic lung & & & Renal & 6 \\
\hline & disease & 1 & & Meninglts & 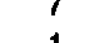 \\
\hline & Apnoea & 1 & & Septicaemia & 1 \\
\hline & Laryngomalacia & 1 & & $\begin{array}{l}\text { Abscess } \\
\text { Onhthalmia }\end{array}$ & 3 \\
\hline \multirow{6}{*}{$\begin{array}{l}\text { Gastroentero- } \\
\text { logical }\end{array}$} & Nonspecific & & & Hepatitis & $i$ \\
\hline & abdominal pain & 4 & \multirow{3}{*}{$\begin{array}{l}\text { Neurological } \\
\text { Syndromes } \\
\text { Oncology }\end{array}$} & & 5 \\
\hline & Gastroenteritis & 44 & & & 2 \\
\hline & Giardiasis & 1 & & $\begin{array}{l}\text { Central nervous } \\
\text { eyetom }\end{array}$ & 2 \\
\hline & $\begin{array}{l}\text { Buda-Chlẩ } \\
\text { syndrome }\end{array}$ & 1 & \multirow{4}{*}{$\begin{array}{l}\text { Cystic fibrosis } \\
\text { Neonate } \\
\text { Renal }\end{array}$} & Exacerbation & 2 \\
\hline & Haematemesis & 1 & & & 6 \\
\hline \multicolumn{2}{|l|}{ Investigation } & 3 & & Nephrosis & 1 \\
\hline \multicolumn{2}{|l|}{ Poisoning } & 5 & & Nephritis & 3 \\
\hline \multirow{2}{*}{ Fever } & Nonspecific & 1 & Miscellaneous & Magnetic & \\
\hline & Viraemia & 10 & \multirow{2}{*}{$\begin{array}{l}\text { Inborn errors of } \\
\text { metabolism }\end{array}$} & resonance imaging & 1 \\
\hline Surgery & Diagnosis & 9 & & & 3 \\
\hline
\end{tabular}

the womenfolk, in the extended family pattern prevalent in the United Arab Emirates.

Hospital utilization and disease severity appear to differ between the two areas. $\mathrm{Pa}$ tients are sicker by the time they are admitted to hospital in the Emirates, as judged by the consultants. This may reflect the services in primary health care facilities here or a tendency to use specialist assessment earlier in the United Kingdom. Our data, which appear to be the first published in the Emir- ates on this subject, may be useful in that they reflect the disease patterns seen in the United Arab Emirates. It may thus help in the planning of paediatric training. It does not, however, address the subjects of neonatal care and oncology; the latter has been addressed elsewhere [4].

The patterns of illness in the national population seen at Tawam Hospital reflect those of industrialized countries and not those seen in developing countries else- 
where. Some conditions commonly seen in developing countries were not seen in our patients; for example, severe malnutrition (kwashiorkor), tuberculosis and helminthiasis. This is probably a reflection on the rapid improvement in the socioeconomic conditions in the country since oil wealth became available about 30 years ago. These findings need to be reflected in fu- ture health planning and paediatric training in the United Arab Emirates.

\section{Acknowledgement}

The authors wish to thank Pamela Roberts for data analysis and secretarial help and the nursing and clerical staff of the paediatric ward, Tawam Hospital.

\section{References}

1. Goodman DC et al. Why are children hospitalized? The role of non-clinical factors in pediatric hospitalizations. Pediatrics, 1994, 93:896-902.

2. Perrin JM et al. Variation in rates of hospitalization of children in three urban communities. New England journal of medicine, 1989, 320:1183-7.

3. MacFaul R, Glass EJ, Jones S. Appropriateness of paediatric admission. Ar- chives of disease in childhood, 1994, 71:50-8.

4. Mpofu C, Revesz T. History and current state of pediatric oncology and hematology in the United Arab Emirates. Pedjatric hematology and oncology, 1996, 3:1-7. 